\title{
Magdalena Stefańska
}

Poznań University of Eonomics and Business

e-mail: magdalena.stefanska@ue.poznan.pl

\section{THE RELATIONSHIP BETWEEN THE PERCEPTION OF THE COMPANY AND EMPLOYEE ATTITUDE IN THE CONTEXT OF CSR - THE RESULTS OF THE EMPIRICAL STUDY ${ }^{1}$}

\section{RELACJA POMIĘDZY WIZERUNKIEM SPOLECZNIE ODPOWIEDZIALNEGO PRZEDSIĘBIORSTWA A ZAANGAŻOWANIEM PRACOWNIKA - WYNIKI BADAŃ EMPIRYCZNYCH}

DOI: $10.15611 /$ pn.2018.520.12

JEL Classification: M50, M51, J89

\begin{abstract}
Summary: The considerations in this article address the issue of the relationship between the perception of the organization and the attitude of employees from the perspective of the employer's activities in the area of social responsibility. Several conclusions were made, based on both literature studies and empirical studies conducted among the employees of trade companies. Firstly, the existence of a connection between the perception of the employer and the level of their involvement in CSR activities was confirmed. The relationship between the perception of the organization and the influence of the immediate manager on this evaluation was also indicated. However, no relationship was found between the selected proenvironmental activities of the employee undertaken on a personal level, and their level of involvement in the workplace, or their perception of the employer.
\end{abstract}

Keywords: CSR, employees engagement, perception of the employer, trade organizations.

Streszczenie: Rozważania zawarte $\mathrm{w}$ niniejszym artykule podejmują zagadnienie relacji między postrzeganiem organizacji a postawą pracowników z perspektywy działań pracodawcy w obszarze społecznej odpowiedzialności. Na podstawie studiów literaturowych i badań empirycznych przeprowadzonych wśród pracowników firm handlowych sformułowano kilka wniosków. Po pierwsze, potwierdzono istnienie związku między postrzeganiem pracodawcy a poziomem jego zaangażowania w działania CSR. Wskazano na obecność związku między postrzeganiem organizacji a wpływem bezpośredniego przełożonego na tę ocenę. Nie wyka-

${ }^{1}$ The research described in this paper was funded by the NCN under the grant No. DEC-2011/03/B/ HS4/03576. 
zano jednak związku między wybranymi działaniami proekologicznymi pracownika na gruncie prywatnym a jego zaangażowaniem w miejscu pracy oraz postrzeganiem pracodawcy.

Słowa kluczowe: CSR, zaangażowanie pracowników, postrzeganie pracodawcy, sieci handlowe.

\section{Introduction}

The body of research in the field of corporate social responsibility has increased significantly in recent years. Researchers have focused on various aspects in their publications: some of the texts raise the issue of the impact of CSR on the creation of economic and social value [Porter, Kramer 2006], or a different approach to the idea of CSR depending on region [Matten, Moon 2008], different stage of CSR development in Polish enterprises [Rojek-Nowosielska 2017], stage of CSR advancement in SME [Kaźmierczak 2017; Teneta-Skwiercz 2013], while other studies refer to the assessment of the impact of social responsibility on employees and the image of an organisation [Lee et al. 2013; Stefańska 2014; Turban, Greening 1996; Greening, Turban 2000]. Part of the researchers' scientific work seeks to verify or develop new tools to analyse employees' CSR [Turker 2009] or reporting about CSR [Adamczyk 2013; Fijałkowska 2015]. Yet other publications are still of the conceptual nature and aim at locating this idea in various theoretical trends and its interpretation in various contexts [Garriga; Melé 2004]. There are also interesting publications that have been emerging in the light of criticism of this idea [Jenkins 2004].

The considerations contained in this article address the issue of the relationship between the organisation and the employees from the perspective of the employer's activities in the area of corporate social responsibility.

\section{Theoretical foundation}

The previous studies which concentrate on employees as key stakeholders, explain the relationship between CSR initiatives and employees' attitudes and explain its meaning for human resource management. Some research studies confirm that CSR initiatives can enhance the performance of sales staff - based on the example of a cause related to marketing campaigns [Larson et al. 2008]. They can also influence employees' commitment to the organisation [Choi, Yu 2014], or their identification with the company [Turban, Greening 1996; Greening, Turban 2000].

In contrast to other studies on the role of CSR in the organisation, the following article includes the employee's own attitude and their tendency to be engaged in proecological and pro-social initiatives as an additional determinant of the perception of the organisation. One of the main reasons for raising this topic is the fact that increasingly more attention is being paid in publications to building an internal 
prestige of the organisation based on CSR, and to seeking different ways to increase employee's involvement. Terms such as employer branding or employee engagement tend to appear more frequently both in theoretical studies and in business practice [Stefańska 2017]. Moreover, CSR is closely related to the above-mentioned terms because building an employer's prestige or providing satisfaction with the workplace is related to the responsibility of an organisation. Some research studies demonstrate that employee attitudes and behaviours are heavily influenced by what employees consider their organisation's actions to be [Cropanzano et al. 2001].

However, it is worth emphasizing that the attitude of employees to the employer's CSR activities may, but does not need to, trigger specific behaviour at work and in the relationships with stakeholders. This puts managers in doubt about the validity of CSR implementation. It appears that the occurrence of benefits from a CSRbased attitude depends on, for instance, the knowledge and attitude of the employees themselves, the relationships within the workplace, as well as the general attitude towards environmental protection or the tendency to engage in pro-social initiatives. This individual employee's capital can be one of the factors affecting the level of acceptance of the actions of the employer and his overall assessment. Undoubtedly, CSR diffusion in the organisation and beyond is expected - to strengthen a positive internal image, as well as to transfer the satisfaction from an employer to the relationship with the environment. This is indicated, among other things, by C.B. Bhattacharya, S. Sen and D. Korschun [2011, pp. 29-30; also Lin et al. 2012, pp. 83-93], according to whom:

- CSR can indirectly strengthen the company's ability to meet the needs of buyers through the observation and behaviour of employees,

- customers' belief regarding the social involvement of employees gives rise to greater acceptance of lower/ worse-quality services,

- thanks to CSR it is possible to achieve a greater level of employees' orientation towards meeting the needs of customers,

- socially engaged enterprises attract better employees, which stems from, among other factors, the employees' expectations to be identified with organisations which have a positive image,

- enterprises that have a greater share of women in top management engage more resources in CSR (more specifically in strategic philanthropy), and implement CSR activities in a wider scope and of higher quality [Soares et al. 2011].

This is also confirmed by research, albeit conducted with a small sample, carried out among CSR managers [Andrejczuk 2016]. In addition to the benefits of CSR, the author points out the barriers to the development of CSR in relations with employees, among which she indicates a lack of understanding of the idea in the group of decision-makers and a failure to recognise financial benefits, or a low level of education in this field. It is worth adding that CSR affects employee loyalty (longer work placements) and higher work efficiency, improves index values, lowers both employment turnover and absenteeism rates, builds a good working atmosphere, 
and promotes the acquisition of the best graduates - candidates for work. However, J.M.B. Maximiano has already pointed out that there is a relationship between managers' decisions about the institutionalisation of CSR in the enterprise and the own system of employees' values [Maximiano 2007]. In his opinion, the involvement in activities undertaken under CSR will depend, among other things, on:

- the meaning of the CSR concept for a manager,

- the manager's attitude and involvement (whether there is a consistency between the views and behaviour expressed by a manager and the activities undertaken as part of CSR),

- implications for employees due to their involvement or a lack thereof in the CSR initiatives implemented in the organisation,

- behaviour of other employees, beneficiaries of the CSR initiatives (employees, members of their families, people who are not related to the enterprise, the natural environment).

These are very important conclusions for managers to consider because they point out the need for a strategic approach to the idea of CSR in the organisation. Therefore, within the competence of managers remain, as B. Rok [2004, p. 14] concludes:

- adaptation of the workplace and adaptation of employees,

- determining fair remuneration and motivating,

- providing employees with training and development,

- guaranteeing health and safety at work,

- guaranteeing and adhering to the employment law and respecting human rights.

Hence this article attempts to verify the thesis about the relationship between the social responsibility of the organisation as an employer and the employee's own attitude towards a broadly understood social involvement. Some of the employees are positive about the employer's activities as a part of CSR, others may remain indifferent to this fact, and still others will be sceptical and reserved towards the efforts made by their organisation. These conclusions can be reached from, among others, the studies by P. Rodrigo and D. Arenas [2008]. The diversity of attitudes goes along with the praise or criticism of an employer. Therefore, if the theoretical discourse focuses on whether an enterprise's intentions as to their social responsibility and commitment are genuine, one can understand the doubts and different attitudes of employees towards this issue.

In the light of the aforementioned comments, the following research question can be raised: Is the perception of an organisation determined by its activity in the areas of CSR, and if so, to what extent?

A correlation would mean that it is in the employer's interest to increase the awareness among employees in relation to the CSR objectives of the company's operations - both economic and social. However, in the long run, not only knowledge, but also the attitude of employees and their perception of activities in the area of CSR become significant. Therefore, the question arises of the role of immediate managers 
in shaping the image and in the diffusion of knowledge about the organisation's ethics. Consequently, the following questions have been formulated:

What is the role of the immediate manager in the diffusion of knowledge about the organisation's ethical attitudes and building a positive attitude?

Is there a connection between the employee's own involvement in social responsibility activities at work or beyond, and the image of the employer?

In order to find the answers to the above questions, the author needed to refer to her own empirical research study, which was carried out among shop employees. The objective scope of the study was determined by several premises, among which one can point out the fact that the policy of retail chains towards their employees has changed noticeably in recent years. The chain shops which have declared their social and environmental responsibility have for years intensified their activities in the area of building positive relationships with their employees. Apart from increasing the salaries of employees who have the lowest positions (it is worth referring to the requirement to offer a fair remuneration in line with the CSR concept, although this concept still remains ambiguous on the basis of the theory and practice, which is why this issue has not been addressed in this study, and limited only to stating the change), "employee benefits" programmes have been expanded in the form of medical care packages, layettes for children, funding, etc., and prospective candidates could learn quite easily about the various benefits of job offers from potential employers. Finally, the transparency of working conditions included in the job offers for specific positions (as a derivative of the competition of retail chains for good employees) has become quite noticeable. It can, therefore, be assumed that the involvement of enterprises in creating a positive image also in the context of CSR has significantly increased in this sector, under the influence of some external factors.

\section{Methodology and characteristics of the sample}

The basis for preparing the research tool - a questionnaire - was a set of questions addressed to employees created by D. Turker [2009] as well as the qualitative research by means of in-depth group interviews [Stefańska 2014]. In the survey the questions were formulated based on the five-point Likert scale, where 1 meant "completely disagree", and 5 - "completely agree". In order to extract the variables for the model, the correctness of the statements (items) accepted for the measurement was verified with reference to the homogeneity (reliability) value of the Cronbach alpha scale, which should be above 0.6. A score below 0.6 is considered as "weak" - the higher its value, the greater the accuracy of the scales accepted for analysis. Subsequently, as a result of factor analysis with the use of Varimax rotation, the factors were isolated. In the process of reduction of variables, the basic parameters were established, determining the validity of the methods used. Bartlett's test of sphericity, which was carried out each time, indicated whether the zero hypothesis should be rejected, informing that the correlation matrix of scales is a unit matrix, 
thus recognizing that the data qualify for conducting a factor analysis. Similarly, the statistics of Kaiser-Mayer-Olkin KMO (accepts the values from the interval $<0$; $>$ and should aim for 1) indicates the appropriateness of conducting the factor analysis [Rószkiewicz 2002].

\section{Characteristics of the sample}

The study comprised the employees who deal directly with customer service. 272 employees of retail outlets, representing 60 different commercial enterprises were examined (Table 1). From the respondents, 222 women, who constitute the majority of employees directly serving clients in the FMCG sector, were selected for analysis. The criterion for non-probability sampling of respondents for the study was a service occupation in a retail outlet belonging to a chain, and offering fast-moving consumer goods, clothing or cosmetics.

Table 1. Characteristics of the sample

\begin{tabular}{|c|c|c|}
\hline Age of respondents & Number of responses & Percentage \\
\hline Under 25 & 58 & 27.1 \\
\hline $26-35$ & 77 & 36.0 \\
\hline $36-45$ & 55 & 25.7 \\
\hline 46 and above & 24 & 11.2 \\
\hline Total & 214 & 100.0 \\
\hline Work experience in trade & Number of responses & Percentage \\
\hline Up to 4 years & 69 & 32.7 \\
\hline $4-8$ years & 45 & 21.3 \\
\hline $8-12$ years & 34 & 16.1 \\
\hline $12-16$ years & 24 & 11.4 \\
\hline More than 16 years & 39 & 18.5 \\
\hline Total & 211 & 100.0 \\
\hline Working position & Number of responses & Percentage \\
\hline With decision-making powers & 41 & 19 \\
\hline With no decision-making powers & 177 & 81 \\
\hline Total & 218 & 100 \\
\hline Education & Number of responses & Percentage \\
\hline Elementary & 2 & 1 \\
\hline Vocational & 43 & 21 \\
\hline Secondary & 99 & 45 \\
\hline Post-secondary non-degree & 31 & 14 \\
\hline Degree-level & 41 & 19 \\
\hline Total & 216 & 100.0 \\
\hline
\end{tabular}


Table 1, cont.

\begin{tabular}{|l|c|c|}
\hline \multicolumn{1}{|c|}{ Household } & Number of responses & Percentage \\
\hline A single person with no children & 35 & 16.1 \\
\hline A single person with a child/children & 16 & 7.3 \\
\hline In a relationship, with children & 100 & 45.9 \\
\hline In a relationship, with no children & 67 & 30.7 \\
\hline Total & 218 & 100.0 \\
\hline
\end{tabular}

Source: own research.

\section{The variables selected for the study}

For the needs of this analysis, the variable perception of the organisation (employer) was defined. It consists of opinions that serve to determine employee's satisfaction with the employer, also in an ethical context (Table 2). The independent variables of the analysis arose as a result of calculating the indexes estimated for individual respondents, which were the arithmetic mean of the questions, forming the given factor, separated and verified on the basis of factor analysis. Thus, the role of the immediate manager is defined by 6 opinions (Cronbach's alfa $=0.84$ ) of his $/$ her own activities for environmental protection -3 opinions (Cronbach's alfa $=0.731$ ) as well as taking initiatives in the workplace -4 opinions (Cronbach's alfa $=$ 0.814). The correlation was estimated, the value of which informs whether there are interrelationships between the features, or variables with no clear distinction between their causes or effects [Mynarski 2006].

Table 2. Selected measures of position for the perception of an employer and factors determining them

\begin{tabular}{|l|c|c|c|c|}
\hline \multicolumn{1}{|c|}{ Perception of the organisation (satisfaction with the employer) } & Mean & Median & Mode & SD \\
\hline \multicolumn{1}{|c|}{ 1 } & 2 & 3 & 4 & 5 \\
\hline $\begin{array}{l}\text { I know the ethical standards applicable in the store/ chain of stores } \\
\text { where I work }\end{array}$ & 3.67 & 4 & 4 & 1.17 \\
\hline $\begin{array}{l}\text { I believe that ethical standards are followed in the store/ chain of } \\
\text { stores where I work }\end{array}$ & 3.44 & 4 & 4 & 1.09 \\
\hline My employer treats the employees fairly & 3.37 & 4 & 4 & 1.21 \\
\hline $\begin{array}{l}\text { All employees in the same positions in the store/ chain of stores } \\
\text { are treated in the same way }\end{array}$ & 3.29 & 4 & 4 & 1.22 \\
\hline I am happy to work for this store/ chain of stores & 3.26 & 3 & 4 & 1.15 \\
\hline $\begin{array}{l}\text { My employer cares for the safety and protection of workers' health } \\
\text { more than required by law }\end{array}$ & 3.17 & 3 & 3 & 1.19 \\
\hline I would be happy to work for this employer for as long as possible & 3.11 & 3 & 3 & 1.21 \\
\hline I am proud of working for this store/ chain of stores & 3.07 & 3 & 3 & 1.12 \\
\hline
\end{tabular}


The relationship between the perception of the company and employee attitude...

\begin{tabular}{|c|c|c|c|c|}
\hline 1 & 2 & 3 & 4 & 5 \\
\hline $\begin{array}{l}\text { My employer's behaviour tends to attract people who are eager to } \\
\text { work }\end{array}$ & 3.05 & 3 & 3 & 1.12 \\
\hline I know what my employer is doing to increase job satisfaction & 2.90 & 3 & 2 & 1.19 \\
\hline $\begin{array}{l}\text { My employer helps employees at work and outside work, if } \\
\text { necessary }\end{array}$ & 2.89 & 3 & 3 & 1.23 \\
\hline $\begin{array}{l}\text { My employer offers employees more facilities and benefits than } \\
\text { required by law }\end{array}$ & 2.72 & 3 & 3 & 1.15 \\
\hline \multicolumn{5}{|l|}{ Evaluation of the role of the immediate manager } \\
\hline $\begin{array}{l}\text { My immediate manager ensures that all employees have the same } \\
\text { workloads at weekends and at night }\end{array}$ & 3.56 & 4 & 4 & 1.13 \\
\hline $\begin{array}{l}\text { My immediate manager praises me if I am more involved in } \\
\text { assisting customers, e.g. in locating products }\end{array}$ & 3.38 & 4 & 4 & 1.23 \\
\hline My immediate manager treats all employees equally & 3.34 & 4 & 4 & 1.16 \\
\hline $\begin{array}{l}\text { My immediate manager further communicates my ideas on how to } \\
\text { improve work in the department or the store }\end{array}$ & 3.28 & 3 & 4 & 1.20 \\
\hline $\begin{array}{l}\text { My immediate manager gives me information about the } \\
\text { employer's social responsibility }\end{array}$ & 3.05 & 3 & 3 & 1.26 \\
\hline $\begin{array}{l}\text { My immediate manager informs me sufficiently about the company } \\
\text { initiatives to help people in need, or to help the environment }\end{array}$ & 2.92 & 3 & 4 & 1.22 \\
\hline \multicolumn{5}{|l|}{ Responsibility at the workplace } \\
\hline $\begin{array}{l}\text { I do not hesitate to submit proposals to improve work so that } \\
\text { customers are more satisfied }\end{array}$ & 3.59 & 4 & 4 & 1.12 \\
\hline $\begin{array}{l}\text { I caution colleagues who forget to turn off the light or to turn off } \\
\text { the tap at work }\end{array}$ & 3.50 & 4 & 4 & 1.24 \\
\hline $\begin{array}{l}\text { I reprimand other employees if they do something to the detriment } \\
\text { of customers }\end{array}$ & 3.26 & 3 & 4 & 1.22 \\
\hline $\begin{array}{l}\text { In a store I try to initiate social, charitable or ecological activities } \\
\text { for a specific person or a family (e.g. collection of clothes, food ...) }\end{array}$ & 2.89 & 3 & 3 & 1.19 \\
\hline \multicolumn{5}{|l|}{ Employee's attitude to activities for environmental protection } \\
\hline I try to save water and electricity at home & 4.08 & 4 & 4 & 0.91 \\
\hline I try to sort litter at home & 3.98 & 4 & 5 & 1.02 \\
\hline I buy eco-friendly products for myself and my family & 3.31 & 3 & 3 & 1.11 \\
\hline
\end{tabular}

Source: own research.

The intensity variable of activities in the area of CSR was estimated by choosing answers in the affirmative to the question about CSR initiatives taken by the employer and known to employees (Table 3). 
Table 3. CSR activities of the employer

\begin{tabular}{|c|c|c|c|}
\hline \multirow[t]{2}{*}{ Operations of store chains (employers) } & Yes & No & $\begin{array}{c}\text { I do not } \\
\text { know }\end{array}$ \\
\hline & \multicolumn{3}{|c|}{$\%$} \\
\hline $\begin{array}{l}\text { My employer takes care of waste sorting by placing containers for various types } \\
\text { of waste }\end{array}$ & 73 & 23 & 4 \\
\hline My employer modifies the work schedule for those who want to improve their skills & 71 & 16 & 13 \\
\hline $\begin{array}{l}\text { My employer provides work tools that are not required by law but facilitate the } \\
\text { work (e.g. slicers, glasses, readers, packaging machines) }\end{array}$ & 68 & 21 & 11 \\
\hline My employer limits the use of office paper & 65 & 19 & 15 \\
\hline My employer encourages employees to give their own suggestions to improve work & 65 & 22 & 13 \\
\hline $\begin{array}{l}\text { My employer has the same principles (related to reward, punishment, employment) } \\
\text { for all employees }\end{array}$ & 65 & 20 & 15 \\
\hline My employer grants employees additional discounts/discounts on purchases & 63 & 32 & 5 \\
\hline My employer organizes a collection of used batteries & 61 & 29 & 10 \\
\hline $\begin{array}{l}\text { My employer takes on employees for long-term, rather than for short-term contracts } \\
\text { (e.g. several months) }\end{array}$ & 60 & 28 & 12 \\
\hline My employer investigates the levels of job satisfaction at the workplace & 51 & 34 & 14 \\
\hline $\begin{array}{l}\text { My employer applies the same terms and conditions of employment in given } \\
\text { positions in the entire chain of stores }\end{array}$ & 51 & 20 & 29 \\
\hline My employer organizes the collection of bottle caps & 49 & 38 & 13 \\
\hline $\begin{array}{l}\text { My employer organises charity campaigns for people in need (e.g. orphanages, } \\
\text { homeless shelters) }\end{array}$ & 46 & 32 & 22 \\
\hline My employer offers either financial or material support to employees in urgent need & 44 & 26 & 30 \\
\hline $\begin{array}{l}\text { My employer supports employees voluntarily because it is the right thing to do, and } \\
\text { not because the law requires it }\end{array}$ & 44 & 30 & 26 \\
\hline $\begin{array}{l}\text { My employer has a code of conduct specifying what to do in the case of unethical } \\
\text { behaviour of employees (e.g., spreading rumours, bullying) or corruption }\end{array}$ & 41 & 25 & 34 \\
\hline $\begin{array}{l}\text { My employer does charity work in support of schools, libraries, sports clubs for } \\
\text { children, etc. }\end{array}$ & 33 & 36 & 31 \\
\hline $\begin{array}{l}\text { My employer co-finances employees' holidays/school holidays of employees' } \\
\text { children, etc. }\end{array}$ & 31 & 50 & 19 \\
\hline $\begin{array}{l}\text { My employer encourages employees to volunteer, and to help in employees' own } \\
\text { initiatives }\end{array}$ & 30 & 45 & 25 \\
\hline My employer employs those who are discriminated for various reasons & 30 & 30 & 40 \\
\hline $\begin{array}{l}\text { My employer makes reports (articles) about their social/environmental involvement } \\
\text { available to employees }\end{array}$ & 30 & 42 & 27 \\
\hline $\begin{array}{l}\text { My employer enables employees to improve their qualifications by co-financing } \\
\text { their studies or training courses }\end{array}$ & 28 & 48 & 24 \\
\hline My employer publishes reports on their social and environmental involvement & 25 & 41 & 34 \\
\hline My employer co-finances school supplies for employees' children & 24 & 52 & 24 \\
\hline $\begin{array}{l}\text { My employer has a department or an organisational unit for complaints related to } \\
\text { CSR }\end{array}$ & 21 & 26 & 53 \\
\hline
\end{tabular}

Source: own research. 


\section{Results}

Based on the research results, it can be noticed that the estimated average values, median and dominant, indicate a moderate level of employee satisfaction with the workplace (Table 2). The respondents have some reservations about the employer, which may stem from a number of reasons, e.g. from a sense of loyalty, or more generally from difficulties in expressing a definitive view. A detailed results analysis with respondents divided by age group demonstrates that only two opinions regarding the perception of the employer were statistically significant. For the opinion My Employer cares for the safety and protection of workers' health more than required by law, the average obtained in the group of the oldest employees was 3.75 and among the youngest respondents -3.00 . On the other hand, for the opinion My employer treats employees fairly in the group of the oldest employees, the average was 3.70, while in the group of people aged 36-45 it was 3.04, and for respondents under the age of 25 it was 3.65). This may be related to the fact that it is usually the younger employees who have just started work that are not fully familiar with the working conditions and standards defined by law. By contrast, the oldest employees notice a significant improvement of employment conditions, because their experiences from previous years indicate a lower level of employer activity in this area than evidenced currently. Moreover, the employees' awareness is growing along with the on-going discussion in the media about working in the trade. In addition, employees regardless of their age and seniority largely agree with the opinion that they know the ethical standards in the organisation. However, only $40 \%$ of respondents confirmed that their employer has a code of conduct in the event of irregularities, which may suggest the presence of a cognitive gap resulting from the subjective belief of the employee, in place of actual knowledge based on their own experience. Table 2 also shows other observations. The employees moderately assess the role of the immediate manager in the diffusion of knowledge about CSR. They do not feel sufficiently informed by the superior about CSR issues. Higher means were obtained for the opinions that were more closely related to work - its organisation and commitment - rather than social responsibility. While considering their own initiative at the workplace, they tend to agree with the opinions that they are trying to do their job in the best possible way. However, they do not initiate activities aimed at social goals. The highest means were obtained for the opinions which demonstrate that they are taking pro-environmental steps at home.

Assuming that the perception of the employer is a variable influenced by many factors, hypotheses were formulated regarding the impact on the perception of the organisation of the number of activities undertaken within CSR, the immediate manager, the employee's own involvement in the workplace and the actions taken by him to protect the environment. Of course, the list of factors determining the perception of an organisation is much wider. In particular, it is determined by the organisational culture, the processes taking place in the organisation or in 
relationships with external stakeholders. Nonetheless, this study highlights the potential presence of a relationship between the scope and intensity of initiatives taken by the employer for the benefit of employees or environmental protection, and the diffusion of knowledge about CSR in the organisation. What may affect the result is the values relatively close to the neutral mean, indicating the difficulties of respondents in determining their attitudes. This may be due to the low level of awareness about the employer's activities. The results are presented in Table 4.

Table 4. Correlation coefficients for variables

\begin{tabular}{|l|c|c|c|c|c|}
\hline \multicolumn{1}{|c|}{ Item } & $\begin{array}{l}\text { Employer's } \\
\text { perceptions }\end{array}$ & $\begin{array}{c}\text { Employer's } \\
\text { CSR } \\
\text { activities }\end{array}$ & $\begin{array}{c}\text { Respondent's } \\
\text { pro-environmental } \\
\text { activities outside } \\
\text { of work }\end{array}$ & $\begin{array}{c}\text { The role } \\
\text { of the } \\
\text { immediate } \\
\text { manager }\end{array}$ & $\begin{array}{c}\text { Responsibility } \\
\text { in the } \\
\text { workplace }\end{array}$ \\
\hline $\begin{array}{l}\text { The perception of the } \\
\text { employer }\end{array}$ & 1 & & & & \\
\hline $\begin{array}{l}\text { Employer's CSR } \\
\text { activities }\end{array}$ & $0.453^{* *}$ & 1 & 1 & 1 & \\
\hline $\begin{array}{l}\text { Respondent's pro- } \\
\text { environmental activities } \\
\text { outside of work }\end{array}$ & $0.170^{*}$ & $0.148^{*}$ & & & \\
\hline $\begin{array}{l}\text { The role of the } \\
\text { immediate manager }\end{array}$ & $0.644^{* *}$ & $0.497^{* *}$ & $0.151^{*}$ & 1 \\
\hline $\begin{array}{l}\text { Responsibility in the } \\
\text { workplace }\end{array}$ & $0.303^{* *}$ & $0.307^{* *}$ & $0.415^{* *}$ & $0.346^{* *}$ & \\
\hline
\end{tabular}

${ }^{*}$ Statistically significant correlation at the 0.05 level (two-sided); ${ }^{* *}$ statistically significant correlation at the 0.01 level (two-sided).

Source: own research.

The value of the Pearson's correlation coefficient indicates the existence of a weaker relationship between the employer's perception and the intensity of CSR activities. The Pearson's correlation coefficient is 0.453 . A much higher value of the estimated coefficient was obtained for the influence of the immediate manager on the perception of the organisation. This would confirm the thesis about the importance of managers in building the employer's image, but also the diffusion of employer's knowledge about CSR. The correlation coefficient between the perception of the employer and the involvement of the superiors in building knowledge about the CSR activities of this organisation amounted to $0.644(p<0.01)$. A variable, which shows a weak relation to the employer's perception, is the employee's pro-environmental behaviour outside of work and own CSR initiatives in the workplace. At the same time, the pro-environmental activities of the employee show a connection with the responsibility for the workplace. It can be concluded that responsibility is an immanent feature of an employee, which determines their behaviour regardless of 
whether it is in the work environment or on a personal level. The moderate correlation is evidenced by the CSR's change in CSR activities (both pro-environmental and pro-social) with the role of the immediate manager $(0.497, p<0.01)$.

\section{Conclusions}

The results obtained in this study have enabled the formulation of several conclusions. First of all, it should be noted that employees are quite neutral in what they say about the employer. Only an in-depth analysis allowed the researcher to distinguish groups of employees who were more or less satisfied - but only in relation to their age, not the length of service in trade. The subject of particular interest was to verify whether the perception of the organisation is affected by the scope of its CSR activities. There is a moderate correlation confirming the existence of such a relationship. Thus, the first question can be answered in the affirmative. The question about the role of the immediate manager is also confirmed - there is a stronger correlation with the perception of the organisation than in the previous case. Moreover, the characteristics of the employee's attitude outside of work are reflected in the workplace, in the form of responsibility for the work carried out and the level of commitment. However, there is no relationship with the perception of the organisation. Thus, a certain distinction can be observed - the CSR activities of the employer and the immediate manager on the one hand, as factors showing a stronger relationship and determining the perception of the organisation, and, on the other hand - the employee responsibility or commitment to professional duties and their own pro-environmental attitude as less correlated variables. The conclusion is that the perception of the organisation by employees is conditioned not so much on what actions are taken, but rather to what extent the employees are aware of the role the managers play in the process of raising awareness about CSR. The role of the organisation is therefore to create models of efficient internal communication and institutionalization of CSR, so that the knowledge and understanding of this issue is at its highest possible level within the organisation. The immediate managers in particular should be activated in the matter of diffusion of knowledge about CSR activities of the organisation, because not only are they a source of knowledge about what is happening in the organisation, but they also significantly shape the organisation's internal image. It is also worth emphasizing that the high share of negative responses to the questions about communication within the organisation about CSR confirms the existing imperfections in practice in this area.

\section{Limitations and recommendations for the future}

The research results presented in this study are subject to certain limitations. These stem from the fact that the research was carried out on the basis of a convenience sample, thus it cannot be generalized. However, the results point to some areas which 
should be particularly important and improved by socially responsible employers. The analyses did not include gender or the position of the respondent at work. In the future, it is possible to verify the thesis that the perception of an organisation can be influenced by both demographic variables - e.g. gender, and the job position or the nature of the work performed. Another limitation is related to the variables adopted in the study. The respondent's attitude both in the workplace and at home may be conditioned by a number of factors and be more complex than assumed in this study, such as the incentive system at work, or high costs of energy or water consumption as a factor that particularly encourages a pro-environmental attitude. Nevertheless, the statistical verification carried out makes it possible to note certain relationships.

\section{Summary}

The research results obtained in this study indicate a rather moderate awareness among employees as regards the employer's activity in the area of CSR. In addition, they do not explicitly state that the immediate manager provides them with information about socially responsible activities. The respondents are also not particularly open to undertaking pro-social initiatives at their workplace. It seems that there is a certain gap, which may have its source in a relatively low level of social capital that translates into a modest level of pro-social activity in the workplace, with a simultaneous responsible approach to the duties performed. This creates interesting research areas worth attention in the future.

\section{References}

Adamczyk J., 2013, Raportowanie społecznej odpowiedzialności przedsiębiorstw, Przegląd Organizacji, nr 4, pp. 8-13.

Andrejczuk M., 2016, The development of CSR in Poland as seen by managers, Prace Naukowe Uniwersytetu Ekonomicznego we Wrocławiu, no. 423, pp. 1-16.

Bhattacharya C.B., Sen S., Korschun D., 2011, Leveraging Corporate Social Responsibility, Cambridge University Press, Cambridge.

Choi Y., Yu Y., 2014, The influence of perceived corporate sustainability practices on employees and organisational performance, Sustainability, no. 6, pp. 348-364; doi:10.3390/su6010348.

Cropanzano R., Byrne Z.S., Bobocel D.R., Rupp D.E., 2001, Moral virtues, fairness entities, and other denizens of organisational justice, Journal of Vocational Behaviour, vol. 58, pp. 164-209.

Fijałkowska J., 2015, Raportowanie CSR a kwestie etyki i odpowiedzialności przedsiębiorstw, Prace Naukowe Uniwersytetu Ekonomicznego we Wrocławiu, nr 396, pp. 39-47.

Garriga E., Melé D., 2004, Corporate Social Responsibility theories: Mapping the territory, Journal of Business Ethics, vol. 53, no. 1-2, pp. 51_71.

Greening D.W., Turban D.B., 2000, Corporate social performance as a competitive advantage in attracting a quality workforce, Business and Society, vol. 39, no. 3, pp. 254-280.

Jenkins H.M., 2004, A critique of conventional CSR theory: An SME perspective, Journal of General Management, vol. 29, no. 4, pp. 37-57. 
Kaźmierczak M., 2017, Determinanty zarządzania społecznie odpowiedzialnego w sektorze matych $i$ średnich przedsiębiorstw, Wydawnictwo Uniwersytetu Ekonomicznego w Poznaniu, Poznań.

Larson V.B., Flaherty E.K., Zablah R.A., Brown J.T., Wiener L.J., 2008, Linking cause-related marketing to sales force responses and performance in a direct selling context, Journal of the Academy of Marketing Science, vol. 36, no. 2, pp. 271-277.

Lee E.M., Park S.-Y., Lee H.J., 2013, Employee perception of CSR activities: Its antecedents and consequences, Journal of Business Research, vol. 66, no. 10, pp. 1716-1724.

Lin C.-P., Tsai Y.-H., Joe S.-W., Chiu C.-K., 2012, Modeling the relationship among perceived corporate citizenship, firms' attractiveness, and career success expectation, Journal of Business Ethics, vol. 105 no. 1, pp. 83-93.

Matten D., Moon J., 2008, "Implicit" and "Explicit" CSR: A conceptual framework for a comparative understanding of Corporate Social Responsibility, The Academy of Management Review, vol. 33, no. 2, pp. 404-424.

Maximiano J.M.B., 2007, A strategic integral approach (SIA) to institutionalizing CSR, Corporate Social Responsibility and Environmental Management, vol. 14, no. 4, pp. 231-242.

Mynarski S., 2006, Analiza danych rynkowych i marketingowych z wykorzystaniem programu Excel, Wydawnictwo Akademii Ekonomicznej w Krakowie, Kraków.

Porter M.E., Kramer M., 2006, Strategy and society: The link between competitive advantage and Corporate Social Responsibility, Harvard Business Review, vol. 84, no. 12, pp. 78-92.

Rodrigo P., Arenas D., 2008, Do employees care about CSR programs? A typology of employees according to their attitudes, Journal of Business Ethics, vol. 83, no. 2, pp. 265-283.

Rojek-Nowosielska M., 2017, Społeczna odpowiedzialność przedsiębiorstw. Model - diagnoza - oce$n a$, Wydawnictwo Uniwersytetu Ekonomicznego we Wrocławiu, Wrocław.

Rok B., 2004, Odpowiedzialny biznes w nieodpowiedzialnym świecie, Akademia Rozwoju Filantropii w Polsce - Forum Odpowiedzialnego Biznesu, Warszawa.

Rószkiewicz M., 2002, Narzędzia statystyczne w analizach marketingowych, C. H. Beck, Warszawa,

Soares R., Marquis C., Lee M., 2011, Gender and Corporate Social Responsibility: It's a Matter of Sustainability, http://www.catalyst.org/file/522/gender_and_corporate_social_responsibility_final.pdf (15.05.2012).

Stefańska M., 2014, Rola społecznej odpowiedzialności w tworzeniu przewagi konkurencyjnej przedsiębiorstw handlu detalicznego, Wydawnictwo Uniwersytetu Ekonomicznego w Poznaniu, Poznań.

Stefańska, M., 2017, Employee engagement w zarządzaniu zasobami ludzkimi w sieciach sklepów uwarunkowania i narzędzia badania, Handel Wewnętrzny w Polsce, s. 100-115

Teneta-Skwiercz D., 2013, Uwarunkowania realizacji koncepcji społecznej odpowiedzialności biznesu w przedsiębiorstwach, Wydawnictwo Uniwersytetu Ekonomicznego we Wrocławiu, Wrocław.

Turban D.B., Greening D.W., 1996, Corporate Social Responsibility and organisational attractiveness to prospective employees, Academy of Management Journal, vol. 40, no. 3, pp. 658-672.

Turker D., 2009, Measuring Corporate Social Responsibility: A scale development study, Journal of Business Ethics, vol. 85, no. 4, pp. 411-427. 